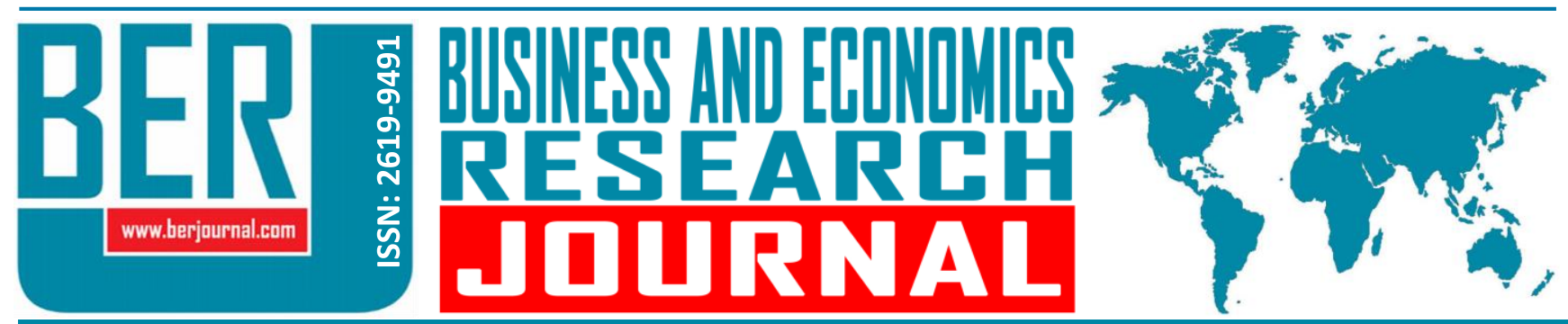

Business and Economics Research Journal Vol. 11, No. 3, 2020, pp. 807-821 doi: 10.20409/berj.2020.283

\title{
The Effect of The E-Commerce Companies' Benevolence, Integrity and Competence Characteristics on Consumers' Perceived Trust, Purchase Intention and Attitudinal Loyalty
}

\author{
Erkan Ozdemir ${ }^{\mathrm{a}}$, Mine Sonmezay ${ }^{\mathrm{b}}$
}

\begin{abstract}
The purpose of this study is to reveal the effect of consumer perceptions on the benevolence, integrity and competence of e-commerce companies on consumers' perceived trust, purchase intention and attitudinal loyalty. The research data were collected by online survey method. The convenience sampling method was used in the study. The research was conducted between November 29 and December 29, 2019. As a result of the data collection process, 297 questionnaires were collected. The research model was tested with structural equation modeling by using Smart PLS. As a result of the research, significant effects of the integrity and competence characteristics of $e$ commerce companies on the perceived trust by the consumers was found. However, effect of the benevolence of e-commerce companies on the consumers' perceived trust wasn't found. As a result of the research, it was found that the perceived trust has significant effect on the purchase intention and the purchase intention has a significant effect on attitudinal loyalty. As a conclusion, e-commerce companies should improve benevolence, integrity and competence which are the antecedent variables affecting trust in order to increase the consumers' perceived trust. As the perceived trust increases, the level of purchase and attitudinal loyalty of consumers will increase considerably.
\end{abstract}

Keywords: B2C, Benevolence, Competence, Integrity, Perceived Trust, Purchase Intention, Attitudinal Loyalty

JEL: M30, M31, L81

\section{Introduction}

Electronic commerce is a business activity in which electronic and digital tools are used as a new form of business. E-commerce is based on the purchase and sale of products and services through electronic systems (Guo, 2012: 402). E-commerce increases the productivity and competence of businesses. This increasing work capacity is being carried out every day in the world (Mahmood, 2016: 327). As the transaction costs and purchasing costs decrease with the development of e-commerce, this cost reduction makes both the supply and demand sides stronger. In e-commerce, companies can interact with consumers more easily (Falk \& Hagsten, 2015: 258).

The competence to access any product or service at any time and from anywhere provided to consumers by e-commerce attracts consumers (Rigby, 2011: 2). Relatively low priced products, high product variety (Crespo \& Bosque, 2010: 571), reduction of information inconsistencies, reduced research costs,

a Prof., PhD., Bursa Uludag University, Faculty of Economics and Administrative Sciences, Department of Business Administration, Bursa, Turkiye, eozdemir@uludag.edu.tr (ORCID ID: 0000-0003-0903-7638)

b PhD. Candidate, Bursa Uludag University, Institute of Social Sciences, Bursa, Turkiye, mine@sonmezay.com (ORCID ID: 00000002-0965-3353) 
facilitation of comparison between products, time saving, competence to prepare better spending plan and the competence to share consumer opinions freely offered by e-commerce are other factors that makes ecommerce attractive for consumers (Valarezo et al., 2018: 464).

Despite the positive factors affecting the adoption of e-commerce by consumers, in addition to the benefits that consumers will obtain in their purchasing decisions, they also give importance to avoiding any errors and risks they may encounter. Therefore, the risks perceived by consumers can have a significant impact on consumers' online purchasing decisions (Harridge-March, 2006: 757). In e-commerce, consumers' inability to have tangible experiences due to lack of touch may increase uncertainty in consumers, which may increase the risk to be undertaken (Lee et al., 2017: 342). When the risks perceived by the consumers are high, the trust perceived by the consumers also decreases, which then reduces the consumers' online purchase intention (Arshad et al., 2015: 14). The fact that e-commerce companies do not set strategies for building trust in consumers may cause consumers to look for alternative channels (Harridge-March, 2006: 757). This is because, consumers' perceived trust in an e-commerce company plays an important role in their brand loyalty or website loyalty (Martin \& Camarero, 2008: 646).

Trust plays a vital role not only in electronic commerce but also in any business activity. Trust factor is an institutional dimension that companies have in achieving certain goals (Safa \& Solm, 2016: 3). Trust can also be defined as a business relationship dimension that determines the level at which each party feels it can count on the integrity of the promise given by the other party (Sam \& Tahir, 2009: 5). In e-commerce, trust is one of the most important antecedents that affect the purchase intention (Ganguly et al., 2009: 35). Trust is an important requirement for consumers to make transaction on the internet. Trust, which is an important determinant in the direction of consumer behavior of e-commerce companies, is also very important in the success of e-commerce companies (Chen, 2012: 1656). In this sense, in order to increase the competitiveness of e-commerce companies, trust to the website should also be increased (Sam \& Tahir, 2009: 8).

Contrary to traditional business, in e-commerce trust is based on the consumer's trust on shopping process. Trust, which is the key factor in the success of e-commerce, has important effects on customer loyalty (Safa \& Solm, 2016: 3). The general trust of consumers towards an e-commerce business is determined by the benevolence, integrity and abilities of those businesses (Chen \& Dhillon, 2003: 315). Curras-Perez et al. $(2017: 140)$ stated that consumers who are reluctant to shop on a website are less likely to believe in the integrity, benevolence and competence of the website and this can easily guide future behavioral intentions. In this sense, perceived benevolence, integrity and competence dimensions are important determinants of the consumers' perceived trust (Kooli et al., 2014: 310).

This study aims to reveal the effects of consumers' perceptions of e-commerce companies' benevolence, integrity and competence factors on consumers' perceived trust, purchase intention and attitudinal loyalty. Additionally, it is aimed to contribute to the understanding of which factors should be important for e-commerce companies to positively affect the trust of online consumers. It is also aimed to contribute to the literature on this subject theoretically with the results obtained.

In the structure of this article, following the introduction, there is a literature and hypothesis development section within the theoretical framework. After that, the model and hypotheses of the research are taken place. Then, the research methodology and the analysis results obtained are presented. In the last section, the results are compared with the results of similar studies in the literature, discussed and suggestions are presented for the managers of e-commerce companies.

\section{Literature and Hypothesis Development}

Trust plays a vital role in almost any activity that requires monetary transactions (Goh et al., 2013: 143). Especially because of the complexity and diversity of online interaction which results in unpredictable behavior, trust becomes more important in online environment. (Weisberg et al., 2011: 84). Consumers generally evaluate websites rationally, and the features offered by a website have important effects on 
consumer trust. Therefore, consumers share personal and important information only when they trust websites (Oliveira et al., 2017: 154).

\subsection{Benevolence Dimension of E-Commerce Companies and Its Relationship with Perceived Trust}

Benevolence can be expressed as the desire of companies to do good to their consumers by acting out of an egocentric profit motive (; Ambrose \& Johnson, 1998: 264; Safa \& Solms, 2016: 4). Benevolent companies are generally well-intentioned and do not act opportunisticly towards consumers only to ensure their business interests (Koh et al., 2012: 888). Benevolence concept expresses the goodwill steps companies take to prevent consumers from getting harm, beyond meeting the consumer needs (Rampl et al., 2012: 258). Companies are called benevolent if companies act in favor of the consumers when consumers encounter situations that companies do not commit to consumers (Kantsperger \& Kunz, 2010: 6).

In the study of Palvia (2009: 218), where the role of trust dimension in e-commerce is analysed, the effect of benevolence on trust is investigated on 496 business students. As a result of the research, it has been found that the benevolence dimension of companies affects the degree to which consumers trust websites. Oliveira et al. (2017: 160), who investigates consumer trust in e-commerce, suggests that the perceived benevolence will be realized when consumers believe that the e-commerce company is acting in consumers' interests and that the company will do its best to help the consumer in case of need. In another study supporting the aforementioned studies, Hallikainen and Laukkanen (2018: 101) found that the benevolence dimension of companies has a significant positive effect on explaining consumer trust. Contrary to these studies, Safa and Solm (2016: 6) revealed that benevolence does not have a direct effect on consumer trust. In line with the literature discussed above, the first hypothesis of the research was determined as follows:

$\boldsymbol{H}_{1}$ : The benevolence dimension of e-commerce companies has a positive effect on perceived trust in electronic commerce.

\subsection{Competence Dimension of E-Commerce Companies and Its Relationship with Perceived Trust}

The competence of an e-commerce company is based on providing a smooth transaction process (Ribadu \& Rahman, 2019: 5). E-commerce companies must have sufficient knowledge and skills to provide this smooth experience (Kantsperger \& Kunz, 2010: 6; Sharma \& Lijuan, 2013: 420). E-commerce companies are considered to be able in proportion to the power it has to provide consumers the service they need (Pelet \& Papadopoulou, 2011: 15). Consumers especially focus on companies' competence to meet purchasing needs such as quality, timeliness and cost (Koh et al., 2012: 888). The competence of companies to meet consumer expectations reduces the uncertainty of e-commerce for consumers (Hallikainen \& Laukkanen, 2018: 99).

The competence of a company includes the variety of products and services offered as well as expertise and competence of their work. It will only be possible to establish consumer trust when all these needs are met (Rampl et al., 2012: 258). In their study, Kaur and Quareshi (2015: 769) revealed that believing that companies have high abilities increases consumer trust and hence the purchase intention. However, in their study Brengman and Karimov (2012: 808) found that competence had no effect on consumer trust. In line with the relevant literature, the second hypothesis of the research is determined as follows:

$\boldsymbol{H}_{2}$ : The competence dimension of e-commerce companies has a positive effect on perceived trust in electronic commerce.

\subsection{Integrity Dimension of E-Commerce Companies and Its Relationship with Perceived Trust}

Integrity reflects expectation of consumer who believes that e-commerce companies will act ethically and reliably in fulfilling their promises and adhere to accepted principles and standards (Anakpa \& Yuan, 2011: 369). In this perspective, there is an expectation that an e-commerce company will act with integrity and good intention. In this sense, e-commerce companies which are regarded as honest by consumers are considered to act according to ethical obligations in all processes (Ribadu \& Rahman, 2019: 5). The long-term 
orientation of companies is an important factor in influencing their integrity dimension (Hallikainen \& Laukkanen, 2018: 103).

In their study on the measurement of trust in e-commerce McKnight et al. (2002: 354) revealed that beliefs about company integrity are related to consumers' purchase intention and integrity is the most important determinant that brings consumers to the purchasing stage. In this context, Brengman and Karimov (2012: 809) stated in their study that perceived integrity means reliability, is an important dimension in building consumer trust and doubts about the integrity of e-commerce companies will negatively affect the purchasing intentions of consumers. Companies that are believed, to be honest will have a positive impact on consumers' purchasing intentions by having an essential advantage in creating consumer trust (Kaur \& Quareshi, 2015: 771; Oliveira et al., 2017: 159). In line with the relevant literature, the third hypothesis of the research was determined as follows:

$\boldsymbol{H}_{3}$ : The integrity dimension of e-commerce companies has a positive effect on perceived trust in electronic commerce.

As discussed above, the benevolence, integrity and competence dimensions of companies have a significant impact on consumers' trust in e-commerce companies (Hallikainen \& Laukkanen, 2018: 102). Ecommerce companies' efforts to increase consumers' perception of benevolence, integrity and competence towards companies will increase the overall trust of consumers towards e-commerce companies (Oliveira et al. 2017: 160).

\subsection{Perceived Trust in E-Commerce Companies and Its Relationship with The Purchase Intention}

Trust, which is an important factor in increasing e-commerce, is one of the factors that have the most significant impact on consumers' positive intentions regarding e-commerce (Shah et al., 2013: 572). Consumers' intention to shop online is related to the online shopping experience, which has a significant impact on consumers' purchasing behavior (Oliveira et al., 2017: 156). When consumers find an e-commerce website reliable, they are more motivated to re-purchase from that website (Eid, 2011: 80; Ribadu \& Rahman, 2019: 5). When consumers have a high purchase intention, the e-commerce companies will also have a higher chance of making more profit (Chen \& Teng, 2013: 16). Therefore, it is important for e-commerce companies to learn the factors affecting consumer trust and satisfaction (Goh et al., 2013: 143).

Faqih (2013: 75) stated that increasing consumer confidence directly increases the consumers' intention to shop online. Therefore, the factor of trust in e-commerce is one of the most important factors in the formation of consumer repurchase intention (Safa \& Solms, 2016: 8; Sullivian \& Kim, 2018: 208). In their study, Oliveira et al. (2017: 160) found that the consumers' overall trust in an e-commerce company depends on the reliability of the companies, which significantly affects their online purchasing intentions. In line with the above literature, the fourth hypothesis of the research is determined as follows:

$\boldsymbol{H}_{4}$ : Perceived trust in e-commerce companies has a positive effect on consumers' purchase intention.

\subsection{Purchase Intention from E-Commerce Companies and Its Relationship with Attitudinal Loyalty}

Consumer loyalty can be expressed as a repetition of purchase behavior (Afsar et al., 2013: 552; Safa \& Solms, 2016: 1). In e-commerce, loyalty is very important to retain consumers (Chen et al., 2015: 1296). Because the competition in e-commerce is only one click away and the low transition costs between companies make it difficult to gain consumer loyalty (Chang \& Chen, 2008: 411). In addition, e-loyalty can lead to more word of mouth marketing and willingness to pay for consumers (Srinivasan et al., 2002: 47).

Toufaily et al. (2013: 1441) states that trust in the website and the information provided by the company is also an important determinant of consumers' online loyalty. As a result, if e-commerce companies that gain consumer trust can create purchase intention in consumers, this intention may also have a positive effect on loyalty. Qureshi et al. (2009: 217) revealed that the involvement of e-commerce companies' in practices that contributes to building trust will increase the repurchase intention and loyalty of consumers, since consumers' online trust has a significant impact on consumers' repurchase. Unlike these studies, Eid 
(2011: 87) argues that trust in e-commerce companies is an independent structure and that consumer trust in e-commerce services is in a weak relationship with consumer loyalty. At this point, the final hypothesis of the research was determined as follows: loyalty.

$\boldsymbol{H}_{5}$ : Consumer purchase intention in e-commerce companies has a positive effect on attitudinal

Figure 1. Research Model

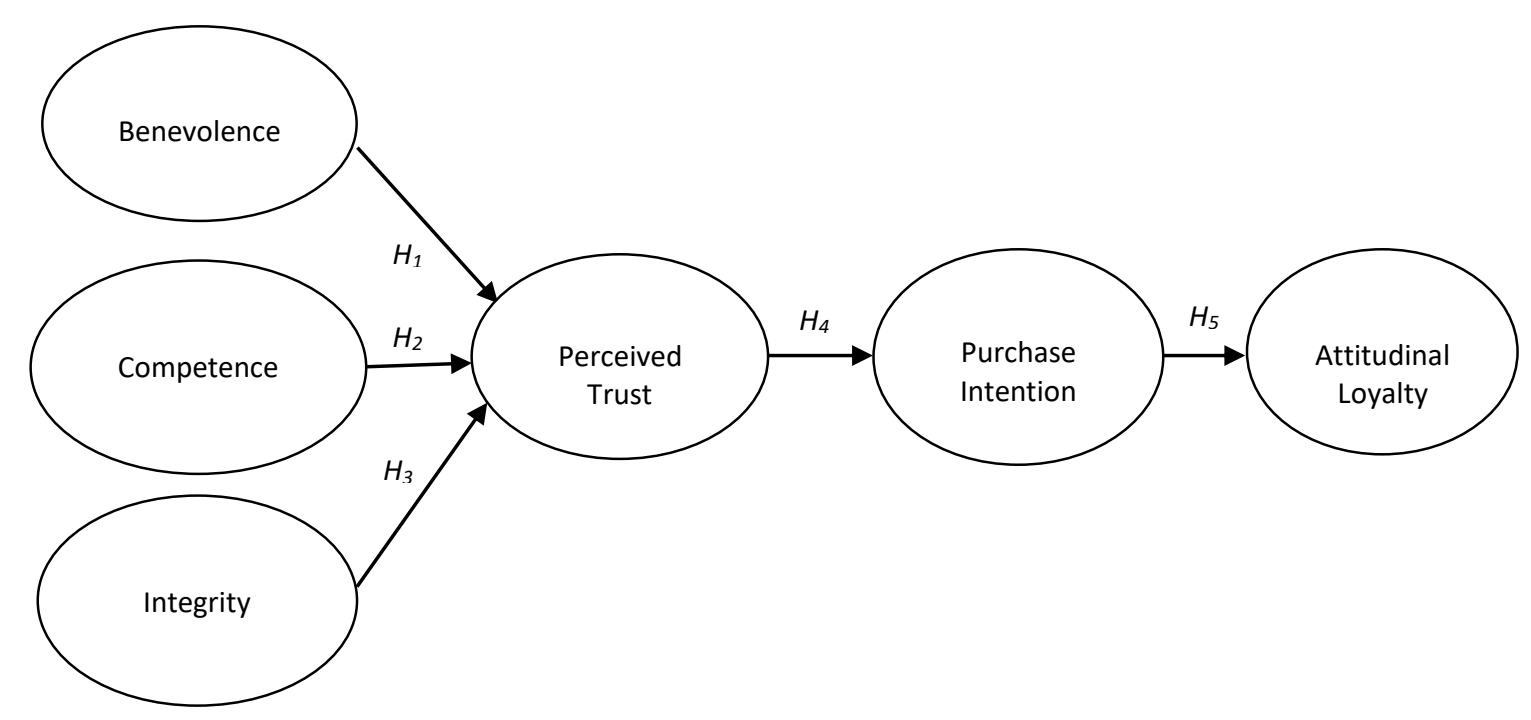

\section{Methodology}

This study aims to reveal the effect the benevolence, integrity and competence of e-commerce companies on consumers' perceived trust, purchase intention and attitudinal loyalty. The research data were collected by online survey method from consumers living in Bursa and shopping online. In the research, convenience sampling method was used considering the cost and time limitations. In order to test the comprehensibility of the questions in the questionnaire and to determine its shortcomings, a pilot study was conducted first. This study was carried out on 30 people between 11 November 2019 and 21 November 2019. As a result of this study, some minor corrections were made on the statements in the questionnaire form. However, no question has been removed from the questionnaire. In the continuation of the pilot study, the research was carried out between November 29, 2019, and December 29, 2019. As a result of the data collection process, 310 questionnaires were collected. However, 13 questionnaires were not included in the analysis due to missing data and errors. Therefore, the analyzes were carried out on 297 questionnaires. IBM SPSS 23 and Smart PLS 3.2.8 package programs were used in the analysis.

The questionnaire form consists of two sections as "categorical questions" and "Likert scale questions". In the first part of the questionnaire, the dimensions of "benevolence" (3 questions), "integrity" (3 questions), "Competence" (4 questions), which affect the perception of trust of the consumers, are addressed. In addition to these questions, there are questions about the dimensions of the research regarding the effect of consumers' trust perception on purchase intention and the effect of purchase intention on consumer attitudinal loyalty. A total of 10 questions about benevolence, integrity and competence were created using the scale questions used in Hallikainen and Laukkanen (2018). 4 questions about trust dimension were created from the study of Oliveira et al. (2017); 3 questions about intention were created using the scale questions used by Chang and Chen (2008) and 6 questions about attitudinal loyalty were created from questions used in Toufaily et al. (2013). Scale questions were evaluated using a 5-point Likert scale. The statements in the scale questions were answered by the respondents considering the e- 
commerce business, where the most frequent purchase was made. Additionally, the questionnaire consists of questions to demonstrate the respondents' demographic characteristics.

\section{Empirical Analysis and Results}

In the analysis of the data, firstly the respondents' demographic characteristics were revealed by frequency analysis. Then, reliability and validity analysis of the scale dimensions used in the studies were tested and the research model was tested by structural equation modeling using Smart PLS.

\subsection{Findings about Respondents' Demographic Characteristics}

The respondents' demographic characteristics are shown in Table 1 below.

Table 1. Respondents' Demographic Characteristics

\begin{tabular}{|c|c|c|c|}
\hline \multicolumn{2}{|l|}{ Characteristics } & \multirow{2}{*}{$\frac{\mathbf{N}}{176}$} & \multirow{2}{*}{$\begin{array}{c}\% \\
59.26\end{array}$} \\
\hline Gondar & Female & & \\
\hline Genue! & Male & 121 & 40.74 \\
\hline \multirow{5}{*}{ Age } & $15-24$ & 36 & 12.12 \\
\hline & $25-34$ & 130 & 43.77 \\
\hline & $35-44$ & 97 & 32.66 \\
\hline & $45-54$ & 27 & 9.0 \\
\hline & 55 and over & 7 & 2.36 \\
\hline \multirow{2}{*}{ Marital Status } & Single & 142 & 47.81 \\
\hline & Married & 155 & 52.19 \\
\hline \multirow{6}{*}{ Education } & Primary Education & 1 & 0.34 \\
\hline & High School & 6 & 2,02 \\
\hline & Associate Degree & 28 & 9,43 \\
\hline & Undergraduate & 169 & 56,90 \\
\hline & Master & 81 & 27.27 \\
\hline & Doctorate & 12 & 4,04 \\
\hline \multirow{6}{*}{ Occupation } & Student & 63 & 21.21 \\
\hline & Private Sector Employee & 116 & 39.06 \\
\hline & Public Employee & 54 & 18.18 \\
\hline & Employer & 47 & 15.82 \\
\hline & Retired & 7 & 2.36 \\
\hline & Unemployed & 10 & 3.37 \\
\hline \multirow{10}{*}{$\begin{array}{l}\text { Monthly } \\
\text { Income }\end{array}$} & 1000 Turkish Lira (TL) and below & 43 & 14.48 \\
\hline & 1001 TL-2000 TL & 47 & 15.82 \\
\hline & 2001 TL-3000 TL & 36 & 12.12 \\
\hline & 3001 TL-4000 TL & 28 & 9.43 \\
\hline & $4001 \mathrm{TL}-5000 \mathrm{TL}$ & 52 & 17.51 \\
\hline & $5001 \mathrm{TL}-6000 \mathrm{TL}$ & 34 & 11.45 \\
\hline & $6001 \mathrm{TL}-7000 \mathrm{TL}$ & 22 & 7.41 \\
\hline & 7001 TL-8000 TL & 3 & 1.01 \\
\hline & 8001 TL-9000 TL & 13 & 4.38 \\
\hline & $9000 \mathrm{TL}$ and above & 19 & 6.39 \\
\hline & Total & 297 & 100 \\
\hline
\end{tabular}


As shown in Table 1, the percentage of male participants $(59 \%)$ is higher than that female participants (41\%). The majority of the participants are between the ages of $25-34$ (43.77\%). There is a low difference in terms of the marital status of the participants. In terms of educational status, the rate of undergraduate graduates $(56.90 \%)$ is quite high. It is seen that a significant part of the participants (39.06\%) are private sector employees. In terms of monthly income, it is seen that approximately $29 \%$ of the participants have a monthly income between 4001-6000 Turkish Liras (TL). The research was carried out on people who did online shopping.

\subsection{Results of Measurement Model}

To test the validity and reliability of the proposed research model, the measurement model was first analyzed. Then, to test the hypotheses, the research model was analyzed using structural equation modeling (SEM). SEM analysis is one of the most used statistical techniques in marketing in recent years (Henseler, 2017). In this study, PLS SEM technique was preferred due to its advantages such as nonparametric structure, ability to process complex models, statistical power and working with small samples instead of covariancebased SEM (Sarstedt et al., 2017).

Within the scope of the reliability and validity analysis of the dimensions in the research, internal consistency reliability, convergent validity, and discriminant validity analyzes were performed. Firstly, Cronbach's Alfa and Composite Reliability (CR) values were calculated to measure the consistency of the items in the dimensions. For the analysis of convergent validity, the Average Variance Extracted (AVE) values were calculated. In addition, the factor loading of each item was evaluated. In the literature, it is stated that factor loadings should be above 0.50, Cronbach's Alpha and CR values should be above 0.70 , and the AVE value should be above 0.50 (Hair et al., 2014).

The Cronbach's alpha value regarding the overall reliability of the scale consisting of 23 items used in this research was found to be 0.894 . Since this result is over the treshold value 0.70 accepted in the literature, it can be stated that the reliability of the scale is high. The measurement model analysis results can be seen in the Table 2 below. Hair et al. (2014) state in their studies that factor loading should be over 0.50 and ideally should exceed 0.70 . When Table 2 is examined, it is shown that convergent validity is met since the AVE values of the dimensions are between 0.620 and 0.867 .

Tablo 2. Results of Measurement Model

\begin{tabular}{|c|c|c|c|c|c|c|}
\hline 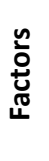 & Items & $\begin{array}{l}\text { Codes of } \\
\text { Items }\end{array}$ & $\begin{array}{l}\text { Factor } \\
\text { Loading }\end{array}$ & $\begin{array}{l}\text { Cronbach's } \\
\text { Alpha }\end{array}$ & $\begin{array}{l}\text { Composite } \\
\text { Reliability }\end{array}$ & $\begin{array}{c}\text { Average } \\
\text { Variance } \\
\text { Extracted } \\
\text { (AVE) }\end{array}$ \\
\hline \multirow{3}{*}{ 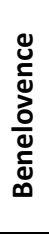 } & $\begin{array}{l}\text { I believe website administrators will do the best } \\
\text { for me. }\end{array}$ & B1 & 0.802 & \multirow{3}{*}{0.696} & \multirow{3}{*}{0.830} & \multirow{3}{*}{0.620} \\
\hline & $\begin{array}{l}\text { If I need help, website administrators will do their } \\
\text { best to help me }\end{array}$ & B2 & 0.786 & & & \\
\hline & $\begin{array}{l}\text { Website administrators take care not only of } \\
\text { themselves, but also of my kindness. }\end{array}$ & B3 & 0.774 & & & \\
\hline \multirow{4}{*}{ 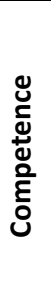 } & $\begin{array}{l}\text { The web site executives are competent and } \\
\text { effective. }\end{array}$ & C1 & 0.831 & \multirow{4}{*}{0.860} & \multirow{4}{*}{0.905} & \multirow{4}{*}{0.704} \\
\hline & $\begin{array}{l}\text { The web site executives perform their role of giving } \\
\text { advice very well. }\end{array}$ & C2 & 0.799 & & & \\
\hline & $\begin{array}{l}\text { Overall, the web site executives are capable and } \\
\text { proficient. }\end{array}$ & C3 & 0.882 & & & \\
\hline & $\begin{array}{l}\text { In general, the web site executives are very } \\
\text { knowledgeable about their own merchandise. }\end{array}$ & C4 & 0.842 & & & \\
\hline
\end{tabular}


The Effect of The E-Commerce Companies' Benevolence, Integrity and Competence Characteristics on Consumers' Perceived Trust, Purchase Intention and Attitudinal Loyalty

Tablo 2. Results of Measurement Model (Continued)

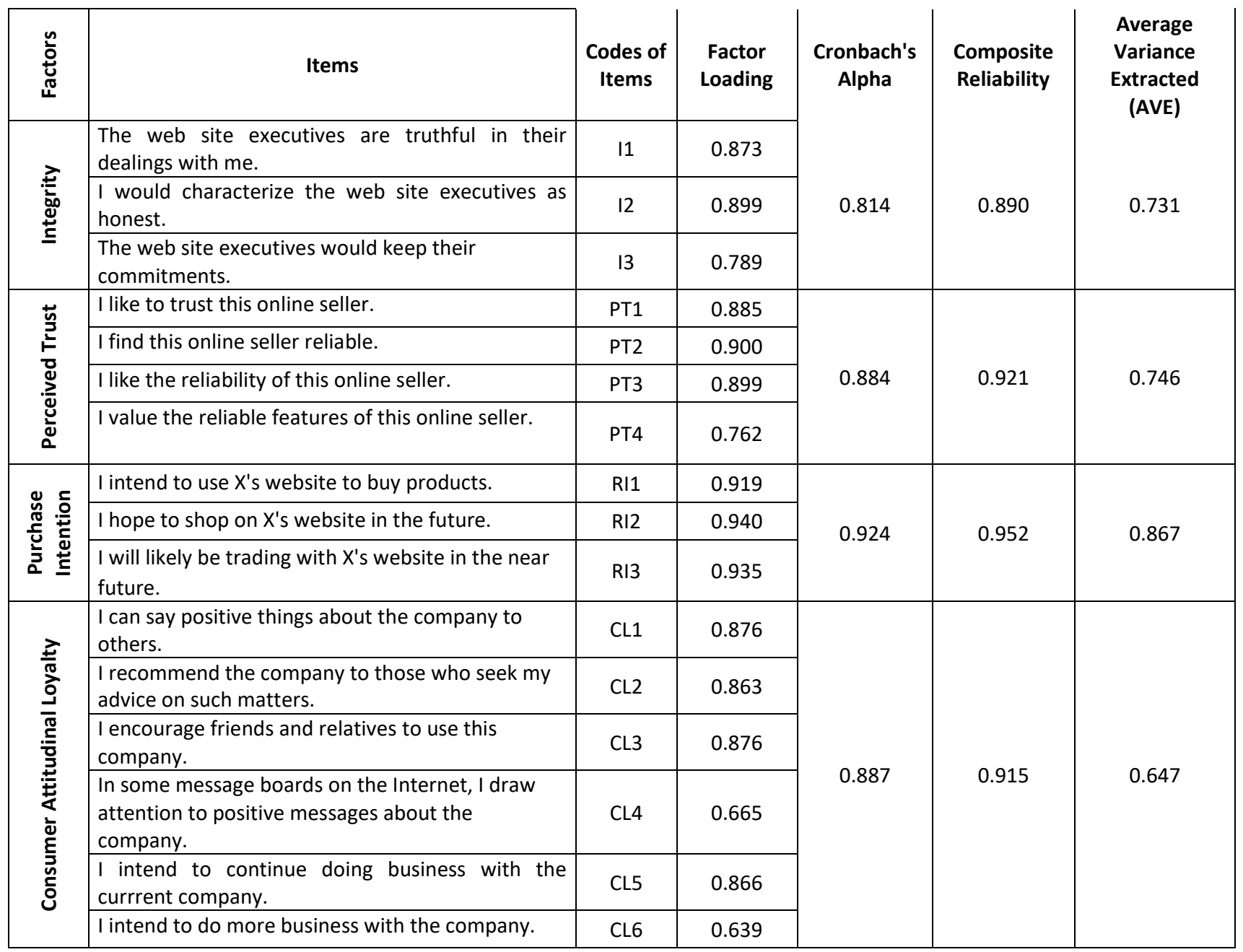

When Table 2 is analyzed, it is seen that Cronbach's Alpha values of the factors used in the analysis are between 0.696 and 0.924 , and the CR values are between 0.830 and 0.952 . Therefore, reliability and internal consistency of the dimensions in the scale were met.

In this study, Fornell and Larcker (1981) and Henseler et al. (2015) recommended criteria were used. According to the Fornell and Larcker (1981) criteria, the square root of the AVE values of the dimensions included in the study should be higher than the correlation between these dimensions. Table 3 below shows the results of the discriminant validity analysis performed according to the criteria of Fornell and Larcker (1981).

Table 3. Results of the Discriminant Validity Analysis by Forner - Larcker Criterion

\begin{tabular}{|l|c|c|c|c|c|c|}
\hline & $\mathbf{( 1 )}$ & $\mathbf{( 2 )}$ & $\mathbf{( 3 )}$ & $\mathbf{( 4 )}$ & (5) & (6) \\
\hline Benevolence (1) & $\mathbf{0 . 7 8 7}$ & & & & & \\
\hline Competence (2) & 0.526 & $\mathbf{0 . 8 3 9}$ & & & & \\
\hline Consumer Attitudinal Loyalty (3) & 0.530 & 0.697 & $\mathbf{0 . 8 0 4}$ & & & \\
\hline Integrity (4) & 0.604 & 0.608 & 0.584 & $\mathbf{0 . 8 5 5}$ & & \\
\hline Perceived Trust (5) & 0.443 & 0.623 & 0.735 & 0.573 & $\mathbf{0 . 8 6 4}$ & \\
\hline Purchase Intention (6) & 0.441 & 0.535 & 0.754 & 0.507 & 0.619 & $\mathbf{0 . 9 3 1}$ \\
\hline
\end{tabular}

Note: The square root of AVE values is shown on the diagonal and printed in bold; non-diagonal values are the latent variable correlations. 
When Table 3 is analyzed, it is seen that the square root of the AVE value of each dimension is higher than the correlation between the other dimensions. Therefore, it can be stated that the criteria proposed by Fornell and Larcker (1981) are met.

The HTMT criterion (Heterotrait-Monotrait Ratio) as suggested by Henseler et al. (2015) expresses the ratio of the average value of the correlations of the expressions of all variables in the study to the geometric mean of the correlations of the expressions of the same variable. According to Henseler et al. (2015), HTMT value should be below 0.85 . Table 4 represents the HTMT values for discriminant validity.

Table 4. Results of the Discriminant Validity Analysis by HTMT Criterion

\begin{tabular}{|l|c|c|c|c|c|c|}
\hline & (1) & (2) & (3) & (4) & (5) & (6) \\
\hline Benevolence (1) & & & & & & \\
\hline Competence (2) & 0.677 & & & & & \\
\hline Consumer Attitudinal Loyalty (3) & 0.674 & 0.794 & & & & \\
\hline Integrity (4) & 0.811 & 0.725 & 0.686 & & & \\
\hline Perceived Trust (5) & 0.564 & 0.709 & 0.826 & 0.672 & & \\
\hline Purchase Intention (6) & 0.547 & 0.598 & 0.819 & 0.584 & 0.682 & \\
\hline
\end{tabular}

When Table 4 is analyzed, it is seen that HTMT values of the dimensions in the analysis are below the threshold. Therefore, it can be stated that the conditions regarding HTMT criteria proposed by Henseler et al. (2015) are also met.

When Table 3 and Table 4 are evaluated, discriminant validity is provided between the dimensions in this scale and the scale dimensions were found to be suitable for SEM analysis.

\subsection{The Results of the Structural Equation Modeling Analysis}

After the analysis of the measurement model, the research model was analyzed by PLS-SEM. The dimensions of benevolence, integrity and competence in the model are exogenous variables. Perceived trust, purchase intention and perceived attitudinal loyalty dimensions are endogenous variables. In the evaluation of the model, basic measurements such as $R^{2}, \beta$ and $t$-values ( $t$ value $\left.>1.96\right)$ and predictive power $\left(Q^{2}\right)$ and effect size (f2) values were used. PLS algorithm for the measurement model and Blindfolding analysis to calculate the predictive power $\left(Q^{2}\right)$ value were run. To measure the significance of PLS path coefficients, $t$ values were recalculated by taking 5000 sub-samples from the sample with the bootstrapping technique. Structural equation modeling analysis results are shown in Table 5 below.

Table 5. The Results of the PLS SEM Analysis

\begin{tabular}{|c|c|c|c|c|c|c|}
\hline Hypothesis & Path & $\begin{array}{c}\text { Path } \\
\text { Coefficients }\end{array}$ & $\begin{array}{c}\text { Standard } \\
\text { Deviation }\end{array}$ & $\begin{array}{c}\mathbf{t} \\
\text { Values }\end{array}$ & $\begin{array}{c}\mathbf{p} \\
\text { Values }\end{array}$ & Result \\
\hline $\mathbf{H}_{\mathbf{1}}$ & $\begin{array}{c}\text { Benevolence } \rightarrow \\
\text { Perceived Trust }\end{array}$ & 0.046 & 0.068 & 0.684 & 0.494 & Reject \\
\hline $\mathbf{H}_{\mathbf{2}}$ & $\begin{array}{c}\text { Competence } \rightarrow \\
\text { Perceived Trust }\end{array}$ & 0.424 & 0.076 & 5.560 & 0.000 & Accepted \\
\hline $\mathbf{H}_{\mathbf{3}}$ & $\begin{array}{c}\text { Integrity } \rightarrow \\
\text { Perceived Trust }\end{array}$ & 0.287 & 0.074 & 3.880 & 0.000 & Accepted \\
\hline $\mathbf{H}_{\mathbf{4}}$ & $\begin{array}{c}\text { Perceived Trust } \rightarrow \\
\text { Purchase Intention }\end{array}$ & 0.619 & 0.046 & 13.551 & 0.000 & Accepted \\
\hline $\mathbf{H}_{\mathbf{5}}$ & $\begin{array}{c}\text { Purchase Intention } \rightarrow \\
\text { Consumer Attitudinal } \\
\text { Loyalty }\end{array}$ & 0.754 & 0.033 & 22.763 & 0.000 & Accepted \\
\hline
\end{tabular}


When Table 5 is analyzed, the results show that all the hypothesized relationships are accepted except $\mathrm{H}_{1}$. The significance value of the $\mathrm{H}_{1}$ hypothesis, which expresses the effect of benevolence dimension on perceived trust was found to be $p=0.494$. In other words, the benevolence of e-commerce companies does not have a significant effect on the trust perceived by consumers. Therefore, the proposed $\mathrm{H}_{1}$ hypothesis was rejected.

$\mathrm{H}_{2}$ hypothesis, which expresses the effect of competence on perceived trust, was also accepted because its significance value was found to be $p=0.000(p<0.05)$. When the standardized ßeta coefficient, which expresses the impact rate regarding this hypothesis is analyzed it can be seen that consumers' perceptions of the e-commerce companies' competence dimension have a significant effect on their perceived trust $(\beta=0.424)$.

The integrity dimension which expresses the $\mathrm{H}_{3}$ hypothesis has a significant $(p=0.000 ; p<0.05)$ effect on perceived trust. Therefore, the proposed $\mathrm{H}_{3}$ hypothesis was accepted. Consumers' perceptions of the integrity dimension of e-commerce companies have a considerable effect on the perceived trust $(\beta=0.287)$.

As a result of the analysis, $\mathrm{H}_{4}$ hypothesis which expresses the effect of perceived trust on consumers' purchase intention from e-commerce companies was also found significant $(p=0.000)$. Therefore, the proposed $\mathrm{H}_{4}$ hypothesis was accepted. Consumers' perceived trust about e-commerce companies has a significant effect on purchase intention from e-commerce companies $(\beta=0.619)$.

The consumers' purchase intention from e-commerce companies also has a significant $(p=0.000)$ impact on consumer attitudinal loyalty. Therefore, the $\mathrm{H}_{5}$ hypothesis, which was the last proposed hypothesis, was also accepted. The consumers' purchase intention from e-commerce companies has a significant effect on consumer attitudinal loyalty $(\beta=0.754)$.

In Table 6 below, $\mathrm{R}^{2}, \mathrm{f}^{2}, \mathrm{Q}^{2}$ and VIF values of structural equation modeling are given and the results obtained are evaluated.

Table 6. Results of $R^{2}, Q^{2}, f^{2}$, and VIF Values

\begin{tabular}{|c|c|c|c|c|c|}
\hline Hypothesis & Path & $\begin{array}{c}R^{2} \\
\text { Value }\end{array}$ & $\begin{array}{c}f^{2} \\
\text { Value }\end{array}$ & $\begin{array}{c}\mathbf{Q}^{2} \\
\text { Value }\end{array}$ & $\begin{array}{c}\text { VIF } \\
\text { Value }\end{array}$ \\
\hline $\mathrm{H}_{1}$ & Benevolence $\rightarrow$ Perceived Trust & \multirow{3}{*}{0.449} & 0.002 & \multirow{3}{*}{0.323} & 1.680 \\
\hline $\mathrm{H}_{2}$ & Competence $\rightarrow$ Perceived Trust & & 0.192 & & 1.693 \\
\hline $\mathrm{H}_{3}$ & Integrity $\rightarrow$ Perceived Trust & & 0.078 & & 1.929 \\
\hline $\mathrm{H}_{4}$ & Perceived Trust $\rightarrow$ Purchase Intention & 0.383 & 0.620 & 0.327 & 1.000 \\
\hline$H_{5}$ & Purchase Intention $\rightarrow$ Consumer Attitudinal Loyalty & 0.568 & 1.314 & 0.359 & 1.000 \\
\hline
\end{tabular}

When Table 6 is examined, it is seen that the VIF values of the variables are below the 5 threshold value (Hair et al., 2011; Ali et al., 2016; Garson, 2016). Therefore, it can be stated that there is no linearity problem among the variables. In the analysis of the inner model, Hair et al. (2017) suggest that the $\mathrm{R}^{2}$ value, which expresses the explained variance of each exogenous latent variable, should also be analyzed. When the $R^{2}$ values for endogenous latent variables in the structural model are $0.75,0.50$ and 0.25 , these values are defined as large, medium and weak, respectively (Hair et al., 2011). When the $R^{2}$ values obtained from the model are analyzed, it can be seen that benevolence, integrity and competence exogenous latent variables explain approximately $45 \%$ of consumers' perceived trust. While perceived trust's explanation rate of purchase intention is about $38 \%$, purchasing intention's explanation rate of consumer attitudinal loyalty is about $57 \%$.

In evaluating the reflective inner model, $\mathrm{f}^{2}$ and $\mathrm{Q}^{2}$ values should also be examined (Hair et al., 2017). The $f^{2}$ value which is expressed as the effect size, refers to the calculation of the increase in $R^{2}$ depending on 
the variance rate of the unexplained part in the exogenous latent variable. With $f^{2}$ values, the effect size of the dimensions is evaluated. Cohen (1988) states that when the $\mathrm{f}^{2}$ value is in the range of $0.02,0.15$ and 0.35 , it has small, medium and large effect sizes, respectively. When Table 6 is analyzed, it is seen that the effect of benevolence and integrity on perceived trust is small and the competence has a medium effect size. The effect of perceived trust on the purchase intention and purchase intention on consumer attitudinal loyalty is quite high.

The $Q^{2}$ value found as a result of blindfolding analysis evaluates the predictive power of the model without including the data of a dimension of a given indicator block into the model (Ali et al., 2016). $Q^{2}$ which is the reuse technique of predictive sampling, is a criterion used in determining the level of predictive power. In order for the model to have predictive power, $Q^{2}$ must be $>0$. Achieved $Q^{2}$ values higher than zero indicate that exogenous variables have predictive power for the endogenous variable in question (Hair et al., 2011; Peng \& Lai, 2012). When Table 6 is examined, the $Q^{2}$ value of the dimensions of benevolence, integrity and competence is 0.323 ; the $Q^{2}$ value of the perceived trust on the purchase intention was found to be 0.327 and the $Q^{2}$ value of the purchase intention on attitudinal loyalty was found to be 0.359 . Since the $Q^{2}$ values found are higher than zero, it can be stated that the model has predictive power.

\section{Discussion and Conclusion}

In this study, it was aimed to reveal the effect of consumer perceptions about the benevolence, integrity and competence of e-commerce companies on consumers' perceived trust, purchase intention and attitudinal loyalty. As a result of the analysis, for the benevolence dimension of e-commerce companies no significant effect on the consumers' perceived trust was found. However, in some studies in the literature, it has been revealed that the benevolence dimension of the companies significantly affects the consumers trust (Palvia, 2009: 219; Hong \& Cho, 2011: 477; Oliveira et al., 2017: 159; Hallikainen \& Laukkanen, 2018: 101). As in this study, in some studies in the literature, it has been concluded that benevolence does not have a direct effect on consumer trust (Safa \& Solm, 2016: 6). However, considering the other studies in the literature, companies can implement applications that can make their consumers feel their benevolence. At this point, e-commerce companies can highlight benevolence related privacy policies in terms of their information processing abilities which consumers are sensitive about (Chen et al., 2010: 545) and effectively use interactive information tools, such as online suggestion systems, filter systems and buying guides, which has different features and facilitate the service provided by the company (Brengman \& Karimov, 2012: 793).

As a result of the analyzes conducted in the study, it was found that the integrity dimension of ecommerce companies has a significant effect $(\beta=0.29)$ on the consumers' perceived trust. The integrity dimension can be perceived as a website incorporating an information privacy policy and promising to protect the privacy of consumers shopping within the framework of this policy (Bernard \& Makienko, 2011: 108). Many studies in the literature have found that integrity has a positive effect on perceived trust. It is expressed that the perceived trust will increase as the degree of belief that companies are reliable increases (Cazier \& Gill, 2003: 1728; Hong \& Cho, 2011: 477; Brengman \& Karimov, 2012: 809; Sharma \& Lijuan, 2013: 420; Kaur \& Quareshi, 2015: 771; Oliveira et al., 2017: 159). The results of the analysis were consistent with the studies in the literature. At this point, companies can help consumers perceive e-commerce websites reliable by using security symbols in online payment transactions and other areas that requires privacy (Eid, 2011: 88). For example, third-generation security certification indicators may reflect that online stores have committed agreements about the integrity of online stores and secure data processing related to consumers (Hallikainen \& Laukkanen, 2018: 103).

As a result of the analyzes carried out in the study, it is found that e-commerce companies' competence dimension has the most significant effect $(\beta=0.42)$ on the consumers' perceived trust. This obtained result has similar results with some studies in the literature (Rampl et al. 2012; Kaur \& Quareshi, 2015). As stated in these studies, it can be easily stated that business capabilities affect the perceived trust and as the business competence increases, the trust perceived by the consumers will increase. At this point, the investment that e-commerce companies will make on their websites will increase their competence to perform online transactions and solve transaction problems (Chen et al., 2010: 545). However, when the 
literature is analyzed, several studies (Cazier \& Gill, 2003; Hong \& Cho, 2011; Brengman \& Karimov, 2012) also found that competence has no effect on consumer trust.

In this study, the effect of perceived trust on consumers' purchase intention from e-commerce companies was also evaluated. As a result of the analysis, it was found that consumers' perceived trust about e-commerce companies has a very high effect $(\beta=0.619)$ on consumers' purchase intention. As a matter of fact, Oliveira et al. (2017: 161) stated that increasing the consumers trust to e-commerce companies will result in positive effect on consumers' purchase intention. It should also be noted that the trust that a consumer will perceive as a result of buying experience from a website will depend on his personal evaluations on the competence, integrity and benevolence of the company based on this experience (AbuShanab \& Ghaleb, 2012: 40). At this point, to increase the level of online trust, companies should always provide honest and reliable information to potential web consumers (Ling et al., 2010: 70).

In this study lastly, the effect of consumers' purchase intention from e-commerce companies on consumer attitudinal loyalty has been investigated. As a result of the analyzes carried out, it was found that the consumers' purchase intention has a very high $(\beta=0.754)$ effect on consumer loyalty. It is seen in the results of the analysis that the perceived trust affects the purchase intention and the purchase intention affects attitudinal loyalty. In this sense, for companies targeting consumer loyalty, it is a crucial requirement for consumers to feel confident (Afsar et al., 2013: 552). In the context of electronic commerce, consumers who do not trust an e-commerce company may not show loyalty to them even if they are generally satisfied with online shopping. As a result, higher trust will lead to stronger e-loyalty (Anderson \& Srinivasan, 2003: 128). Therefore, e-commerce companies should develop strategies to improve dimensions such as consumers' perceived trust and loyalty (Toufaily et al., 2013: 1441). Particularly, given the high costs of gaining new consumers, it is important to examine the factors that affect consumer loyalty (Mahmood, 2016: 325).

As with many studies, this study also has several limitations. The first of these limitations is the fact that the study was conducted on consumers living in Bursa and shopping online. In addition, using convenience sampling method in the study also includes other limitation. Both these limitations negatively affect the generalization of the research results. For this reason, future research should be done on a larger sample and by using random sampling methods. It can also be analyzed in future research whether a similar research model differs according to different demographic features.

\section{Disclosure Statements}

1. The authors of this article confirm that their work complies with the principles of research and publication ethics.

2. No potential conflict of interest was reported by the authors.

3. This article was screened for potential plagiarism using a plagiarism screening program.

\section{References}

Abu-Shanab, E., \& Ghaleb, O. (2012). Adoption of mobile commerce technology: An involvement of trust and risk concerns. International Journal of Technology Diffusion, 3(2), 36-49.

Afsar, A., Nasiri, Z., \& Zadeh, M. O. (2013). E-loyalty model in e-commerce. Mediterranean Journal of Social Sciences, 4(9), 547.

Ali, F., Amin, M., \& Cobanoglu, C. (2016). An integrated model of service experience, emotions, satisfaction, and price acceptance: An empirical analysis in the Chinese hospitality industry. Journal of Hospitality Marketing \& Management, 25(4), 449-475.

Ambrose, P., \& Johnson, G. (1998). A trust-based model of buying behavior in electronic retailing. In: Proceedings of the Fourth Americas Conference on Information Systems (AMCIS), Baltimore, MA. 
Anakpa, M., \& Yuan, Y. (2013). Multidisciplinary trust conceptualization: A general model for customer trust building in e-commerce. In International Conference on Trustworthy Computing and Services, Springer, Berlin, Heidelberg, 366-373.

Anderson, R. E., \& Srinivasan, S. S. (2003). E-satisfaction and e-loyalty: A contingency framework. Psychology \& Marketing, 20(2), 123-138.

Ariffin, S. K., Mohan, T., \& Goh, Y. N. (2018). Influence of consumers' perceived risk on consumers' online purchase intention. Journal of Research in Interactive Marketing, 12(3), 309-327.

Arshad, A., Zafar, M., Fatima, I., \& Khan, S. K. (2015). The impact of perceived risk on online buying behavior. International Journal of New Technology and Research, 1(8), 13-18.

Bernard, E. K., \& Makienko, I. (2011). The effects of information privacy and online shopping experience in ecommerce. Academy of Marketing Studies Journal, 15(1), 97-112.

Brengman, M., \& Karimov, F. P. (2012). The effect of web communities on consumers' initial trust in B2C e-commerce websites. Management Research Review, 35(9), 791-817.

Cazier, J., \& Gill, M. (2003). Values in e-business: Testing value compatibility and trust production in e-commerce, in J. Ross and D. Galletta (Eds.). Proceedings of the 9th Americas Conference on Information Systems, Tampa, FL, 1723-1730.

Chang, H. H., \& Chen, S. W. (2008). The impact of online store environment cues on purchase intention. Online Information Review, 32(6), 818-841.

Chen, H. (2012). The influence of perceived value and trust on online buying intention. Journal of Computers, 7(7), 16551662.

Chen, J. V., Yen, D. C., Pornpriphet, W., \& Widjaja, A. E. (2015). E-commerce web site loyalty: A cross cultural comparison. Information Systems Frontiers, 17(6), 1283-1299.

Chen, M. Y., \& Teng, C. I. (2013). A comprehensive model of the effects of online store image on purchase intention in an e-commerce environment. Electronic Commerce Research, 13(1), 1-23.

Chen, S. C., \& Dhillon, G. S. (2003). Interpreting dimensions of consumer trust in e-commerce. Information Technology and Management, 4(2-3), 303-318.

Chen, Y. H., Chien, S. H., Wu, J. J., \& Tsai, P. Y. (2010). Impact of signals and experience on trust and trusting behavior. Cyberpsychology, Behavior and Social Networking, 13(5), 539-546.

Cohen, J. (1988). Statistical power analysis for the behavioral sciences (2nd ed.). Lawrence Erlbaum Associates, USA.

Crespo, A. H., \& Del Bosque, I. R. (2010). The influence of the commercial features of the Internet on the adoption of ecommerce by consumers. Electronic Commerce Research and Applications, 9(6), 562-575.

Curras-Perez, R., Ruiz, C., Sanchez-Garcia, I., \& Sanz, S. (2017). Determinants of customer retention in virtual environments. The role of perceived risk in a tourism services context. Spanish Journal of Marketing-ESIC, 21(2), 131-145.

Eid, M. I. (2011). Determinants of e-commerce customer satisfaction, trust, and loyalty in Saudi Arabia. Journal of Electronic Commerce Research, 12(1), 78.

Falk, M., \& Hagsten, E. (2015). E-commerce trends and impacts across Europe. International Journal of Production Economics, 170, 357-369.

Faqih, K. M. (2013). Exploring the influence of perceived risk and internet self-efficacy on consumer online shopping intentions: Perspective of technology acceptance model. International Management Review, 9(1), 67-77.

Fornell, C., \& Larcker, D. F. (1981). Evaluating structural equation models with unobservable variables and measurement error. Journal of Marketing Research, 18(1), 39-50.

Ganguly, B., Dash, S. B., \& Cyr, D. (2009). Website characteristics, trust and purchase intention in online stores: An empirical study in the Indian context. Journal of Information Science \& Technology, 6(2), 22-44.

Garson, G. D. (2016). Partial least squares: Regression and structural equation model. USA (Asheboro): Statistical Associates Publishing.

Goh, K. N., Chen, Y. Y., Lai, F. W., Daud, S. C., Sivaji, A., \& Soo, S. T. (2013). A comparison of usability testing methods for an e-commerce website: A case study on a Malaysia online gift shop. In 10th International Conference on Information Technology: New Generations, 143-150.

Guo, M. (2012). A Comparative study on consumer right to privacy in e-commerce. Modern Economy, 3, $402-407$. 
Hair, J. F., Black, W. C., Babin, B. J., \& Anderson, R. E. (2014). Multivariate data analysis (7th ed.). Essex, Pearson Education Limited.

Hair, J. F., Hult, G. T. M., Ringle, C. M., \& Sarstedt, M. (2017). A primer on partial least squares structural equation modeling (PLS-SEM) (2nd ed.). Thousand Oaks, Sage Publications.

Hair, J. F., Ringle, C. M., \& Sarstedt, M. (2011). PLS-SEM: Indeed a silver bullet. Journal of Marketing Theory and Practice, $19(2), 139-152$.

Hallikainen, H., \& Laukkanen, T. (2018). National culture and consumer trust in e-commerce. International Journal of Information Management, 38(1), 97-106.

Harridge-March, S. (2006). Can the building of trust overcome consumer perceived risk online? Marketing Intelligence \& Planning, 24(7), 746-761.

Henseler, J. (2017) Partial least squares path modeling (Editor: Leeflang et al). In advanced methods for modeling markets. International Series in Quantitative Marketing, Springer International Publishing, 361-381.

Henseler, J., Ringle, C.M. and Sarstedt, M. (2015). A new criterion for assessing discriminant validity in variance-based structural equation modeling. Journal of the Academy of Marketing Science, 43(1), 115-135.

Hong, I. B., \& Cho, H. (2011). The impact of consumer trust on attitudinal loyalty and purchase intentions in B2C emarketplaces: Intermediary trust vs. seller trust. International Journal of Information Management, 31(5), 469479.

Kantsperger, R., \& Kunz, W. H. (2010). Consumer trust in service companies: A multiple mediating analysis. Managing Service Quality, 20(1), 4-25.

Kaur, G., \& Quareshi, T. K. (2015). Factors obstructing intentions to trust and purchase products online. Asia Pacific Journal of Marketing and Logistics, 21(21), 1353-1376.

Kim, J., \& Lennon, S. J. (2013). Effects of reputation and website quality on online consumers' emotion, perceived risk and purchase intention. Journal of Research in Interactive Marketing, 7(1), 33-56.

Koh, T. K., Fichman, M., \& Kraut, R. E. (2012). Trust across borders: Buyer-supplier trust in global Business-to-Business e-commerce. Journal of the Association for Information Systems, 13(11), 886-922.

Kooli, K., Ben Mansour, K., \& Rizky, U. (2014). Determinants of online trust and their impact on online purchase intention. International Journal of Technology Marketing, 9(3), 305-319.

Lee, Y. J., Yang, S., \& Johnson, Z. (2017). Need for touch and two-way communication in e-commerce. Journal of Research in Interactive Marketing, 11(4), 341-360.

Ling, K. C., Chai, L. T., \& Piew, T. H. (2010). The effects of shopping orientations, online trust and prior online purchase experience toward customers' online purchase intention. International Business Research, 3(3), 63.

Mahmood, S. F. (2017). E-Commerce, online shopping and customer satisfaction: An empirical study on e-commerce system in Dhaka. International Journal of Entrepreneurship and Development Studies, 4(3), 337-352.

McKnight, D. H., Choudhury, V., \& Kacmar, C. (2002). Developing and validating trust measures for e-commerce: An integrative typology. Information Systems Research, 13(3), 334-359.

Oliveira, T., Alhinho, M., Rita, P., \& Dhillon, G. (2017). Modelling and testing consumer trust dimensions in ecommerce. Computers in Human Behavior, 71, 153-164.

Palvia, P. (2009). The role of trust in e-commerce relational exchange: A unified model. Information \& Management, 46(4), 213-220.

Pelet, J. É., \& Papadopoulou, P. (2011). The effect of e-commerce websites' colors on customer trust. International Journal of E-Business Research, 7(3), 1-18.

Peng, D. X., \& Lai, F. (2012). Using partial least squares in operations management research: A practical guideline and summary of past research. Journal of Operations Management, 30(6), 467-480.

Qureshi, I., Fang, Y., Ramsey, E., McCole, P., Ibbotson, P., \& Compeau, D. (2009). Understanding online customer repurchasing intention and the mediating role of trust: An empirical investigation in two developed countries. European Journal of Information Systems, 18(3), 205-222.

Rampl, L. V., Eberhardt, T., Schütte, R., \& Kenning, P. (2012). Consumer trust in food retailers: conceptual framework and empirical evidence. International Journal of Retail \& Distribution Management, 4(4), 254-272.

Ribadu, M. B., \& Rahman, W. N. W. A. (2019). An integrated approach towards Sharia compliance e-commerce trust. Applied Computing and Informatics, 15(1), 1-6.

Rigby, D. (2011). The future of shopping. Harvard Business Review, 89(12), 65-76. 
Safa, N. S., \& Von Solms, R. (2016). Customers repurchase intention formation in e-commerce. South African Journal of Information Management, 18(1), 1-9.

Sam, M. F. M., \& Tahir, M. N. H. (2009). Website quality and consumer online purchase intention of air ticket. International Journal of Basic \& Applied Sciences, 9(10), 4-9.

San Martín, S., \& Camarero, C. (2009). How perceived risk affects online buying. Online Information Review.

Sarstedt, M., Ringle, C. M., \& Hair, J. F. (2017). Partial least squares structural equation modeling. C. Homburg et al. (Eds.), Handbook of Market Research, Springer International Publishing, 1-40.

Shah, M. H., Okeke, R., \& Ahmed, R. (2013). Issues of privacy and trust in e-commerce: Exploring customers' perspective. Journal of Basic and Applied Scientific Research, 3(3), 571-577.

Sharma, G., \& Lijuan, W. (2014). Ethical perspectives on e-commerce: An empirical investigation. Internet Research, 24(4), 414-435.

Srinivasan, S. S., Anderson, R., \& Ponnavolu, K. (2002). Customer loyalty in e-commerce: An exploration of its antecedents and consequences. Journal of Retailing, 78(1), 41-50.

Sullivan, Y. W., \& Kim, D. J. (2018). Assessing the effects of consumers' product evaluations and trust on repurchase intention in e-commerce environments. International Journal of Information Management, 39, 199-219.

Toufaily, E., Ricard, L., \& Perrien, J. (2013). Customer loyalty to a commercial website: Descriptive meta-analysis of the empirical literature and proposal of an integrative model. Journal of Business Research, 66(9), 1436-1447.

Valarezo, Á., Pérez-Amaral, T., Garín-Muñoz, T., García, I. H., \& López, R. (2018). Drivers and barriers to cross-border ecommerce: Evidence from Spanish individual behavior. Telecommunications Policy, 42(6), 464-473.

Weisberg, J., Te'eni, D., \& Arman, L. (2011). Past purchase and intention to purchase in e-commerce. Internet Research, 21(1), 82-96. 
This Page Intentionally Left Blank 